to animal insulins.

The announcement of FDA approval had been so long expected that neither Genentech's nor Lilly's stock jumped much in response, although Lilly's stock, which has been depressed since its sudden withdrawal of the anti-arthritis drug Oraflex earlier this year, traded a little higher after the FDA announcement on Humulin.

FDA gave approval on the basis of safe performance in trials involving about 400 patients a mere five months after Lilly filed its application. The agency also has in the pipeline applications for genetically-engineered products such as human growth hormones and interferons. Approval can take as long as two years, but the agency has recently undertaken a series of controversial moves to shorten approval time and simplify procedures.

Genentech is the first of the highly competitive biotechnology companies with a product approved for human use. The company's task was enormously eased by the security of the support provided by Lilly, which has exclusive licensing rights and which is estimated to have spent $\$ 100$ million in bringing the product to market. Genentech will receive a royalty on sales which is thought to be in single figures.

Genentech may be following a riskier path in its development of human growth hormone products and gamma interferon. It plans to market these products itself, which explains why it persuaded a group of investors to buy limited partnerships in October, thereby raising $\$ 55$ million for research. This will support work on a human growth hormone product for children who suffer from dwarfism, but since these are few in number the product would also have to be useful in combating CDSS (constitutionally delayed short stature), a problem that afflicts a greater number of people. Ideally, such a product could also help patients with cachexia, a wasting syndrome.

In addition to the limited partnership, in October four Swedish organizations bought $\$ 20$ million in Genentech's outstanding shares, or 571,428 shares at $\$ 35$ per share. (Two weeks later, after the limited partnerships and the FDA announcement, the company's stock reached $\$ 50$ a share.) The four organizations are Alfa-Laval AB, the Wallenberg Foundation, AB Fannyudde, an investment company affiliated with Volvo, and D. Carengie and Co., another investment company. The president and chief executive officer of Alfa-Laval AB, Harry Faulkner, was made a member of Genentech's board of directors. The company also appointed to its board John T. Potts, chief of the Department of Medicine at the Massachusetts General Hospital. Dr David W. Martin, a professor of medicine and biochemistry at the University of California, San Francisco, has been appointed vice-president for research.

Deborah Shapley
Biotechnology index

\section{Biotechnology index beats Dow}

\section{Washington}

Nature's third monthly Biotechnology Index set a new high in October, reaching 140.2 from a base of 100 at the end of June. This increase was greater than either the Industrial Index, the leading index of US industrial trading, or the Standard \& Poor's 400 index of leading industrial stocks. Thus, the biotechnology companies moved parallel to, but ahead of, the market surge that led the Dow Jones mark in the first week of October.

But the performance of the Nature Biotechnology Index may have as much to do with internal factors in the companies themselves as with trends on Wall Street. The "Street" was reacting to continued lowering of inflation and the perception that the US elections, just held, would not upset the direction of the US economy. As one analyst in New York explained, the overall market surge was caused by "institutional money managers getting in who don't want to miss more of the rally". Such managers buy huge blocks of stock and so stay away from smaller companies recent increases in the Dow Jones index finally to break through the 1,000 where such buying would artificially drive up the price.

The analyst went on to suggest that one reason why the Nature index did so well was because two companies in the index are funds and stable enough to ride along with the trend. These are A.B. Fortia of Sweden and Novo Industri A/S of Denmark, which had market capitalizations valued at \$751 million and \$789 million respectively on 29 October, when the index was calculated. The reasons for the rise in stock price of Genetech are outlined in the preceding story.

The other small companies in the index have also done well lately. "There have been no major flubs in the group", one analyst says. For example, the stock of Cetus, in Berkeley, California, rose after the company announced lay-offs and a redirection of its research. This was seen as a net gain for the company, because specialists in biotechnology investment had felt that Cetus was over-extended. Hybritech and Damon of Needham have been getting considerable public attention for their work.

Deborah Shapley large enough to attract some institutional

Nature index of biotechnology stocks

\begin{tabular}{|c|c|c|c|c|c|}
\hline $\begin{array}{l}1982 \\
\text { high }\end{array}$ & $\begin{array}{l}1982 \\
\text { low }\end{array}$ & Company & $\begin{array}{l}\text { Close } \\
\text { previous } \\
\text { month }\end{array}$ & $\begin{array}{l}\text { Close } \\
29 \text { Oct. }\end{array}$ & Change \\
\hline 45 & $16^{1 / 8}$ & A.B. Fortia (Sweden) & $341 / 4$ & $391 / 2 *$ & $51 \frac{1}{4}$ \\
\hline 8 & 2 & Bio Logicals (Canada) & $21 / 2$ & $21 / 4$ & $-1 / 4$ \\
\hline 7 & $35 / 8$ & Bio-Response (USA) & $43 / 4$ & 5 & $1 / 4$ \\
\hline $14^{1 / 8}$ & $73 / 4$ & Cetus (USA) & $83 / 4$ & $93 / 4$ & 1 \\
\hline 11 & $61 / 8$ & Collaborative Research (USA) & $8^{5} / 8$ & $93 / 4$ & $1 / \frac{1}{8}$ \\
\hline $97 / 8$ & $53 / 4$ & Damon (USA) & $71 / 2$ & $91 / 8$ & $13 / 8$ \\
\hline 18 & $81 / 4$ & Enzo-Biochem (USA) & $14 \frac{1}{2}$ & 17 & $21 / 2$ \\
\hline 28 & $6 \%$ & Flow General (USA) & $10 \%$ & $131 / 4$ & $23 / 8$ \\
\hline $473 / 4$ & 26 & Genentech (USA) & $33 \frac{1}{4}$ & $473 / 4 *$ & $14^{1 / 2}$ \\
\hline $91 / 2$ & 7 & Genex (USA) & - & $91 / 4$ & - \\
\hline 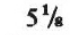 & $2 \frac{1}{4}$ & Genetic Systems (USA) & $31 / 4$ & $51 / 8$ & $\mathbf{1}$ \\
\hline $26^{1 / 4}$ & $95 / 8$ & Hybritech (USA) & $131 / 2$ & $201 / 2$ & 7 \\
\hline $113 / 4$ & 5 & Molecular Genetics (USA) & $10^{3 / 4}$ & $93 / 4$ & -1 \\
\hline 52 & $347 / 8$ & Novo Industri A/S (Den.) & 44 & $471 / 2$ & $31 \frac{1}{2}$ \\
\hline 17 & 8 & Monoclonal Antibodies (USA) & $81 / 4$ & $143 / 4$ & $6^{1 / 2}$ \\
\hline
\end{tabular}

The Nature Biotechnology Index for October, 1982, stands at 140.2, compared with 117.9 last month. Base is 100 as of 25 June 1982. Previous indexes appeared in Nature 12 August, p.599; 9 September, p.101; and 14 October, p.573. Close-of-month prices are the closing prices on the last Friday of each month. Where stocks are traded over the counter, the price quoted is the bid price. For stocks traded on the American and New York Stock Exchanges, the price quoted is the transaction price. Data from E.F. Hutton, Inc.

*High or low for this calendar year.

In response to readers' comments on the Biotechnology stock index, its composition has this month been changed. Thus Collagen Inc. - a company that does not use new biotechnology has been replaced by Genex, an important small company which made its first public stock offering after the close of the previous month's index.

This has been done by deleting Collagen's share of the market value of all the companies on 29 October and reallocating that share proportionally among the remaining 14 companies in the index. Then the total market value of Genex shares on that date (an estimated \$106 million) was added to the market values of the 14 companies and a new set of market shares calculated. This new set of divisors will be used in the calculation of future indexes.

In response to a further suggestion, there follows information on the trading symbols and, where appropriate, the stock exchanges on which the shares are traded. Most shares are traded over the counter (through brokers). Fortia (FOPHY); Bio Logicals (BIOLF); Bio-Reponse (BIOR); Cetus (CTUS); Collaborative Research (CRIC); Collagen (CGEN); Damon (DMN NYSE); Enzo-Biochemi (ENZO); Flow General (FGN); Genentech (GENE); Genetic Systems (GENS); Genex (GNEX); Hybritech (HYBR); Molecular Genetics (MOGN); Novo Industri A/S (NVO - NYSE); Monoclonal Antibodies (MABF). 